\title{
N-terminal Amino Acid Sequence Comparison of Hemocyanin Subunits from the Spiders, Argiope amoena, Argiope bruennichii, Araneus ventricosus, Nephila clavata and Dolomedes sulfureus.
}

\author{
Yasuhiro TAKASU ${ }^{1)}$ and Hiroaki SUGITA ${ }^{2) *}$

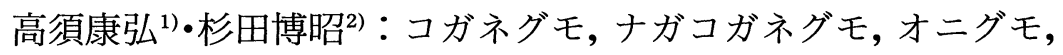 \\ ジョロウグモおよびイオウイロハシリグモの \\ ヘモシアニンサブユニットの $\mathrm{N}$ 末端アミノ酸配列の比較
}

\begin{abstract}
By two dimensional electrophoresis using acrylamide disc and slab gels, hemocyanin hexamers of four araneid spiders Argiope amoena, A. bruennichii, Araneus ventricosus, Nephila clavata, and a pisaurid spider Dolomedes sulfureus were separated completely into individual subunits. Direct protein sequencing of hemocyanin monomer subunits gave the $\mathrm{N}$-terminal sequences for the first 10-25 amino acid residues, except for subunits with blocked amino terminals. From the sequence comparison between the araneid spider's hemocyanin subunits, it is supposed that the araneid spiders share the subunits with similar $\mathrm{N}$-terminal sequences derived from a common ancestral sequence and that duplications of the ancestral sequence occurred in the lineages of $A$. amoena and $N$. clavata or in the common ancestor immediately before the divergence of these two spiders and then in the lineage of $N$. clavata. On the contrary, the pisaurid spider has hemocyanin subunits with unique $\mathrm{N}$-terminal sequences which are not found in any hemocyanin until now.
\end{abstract}

\section{Introduction}

Hemocyanins are extracellar oxygen-carrying proteins in the hemolymph of many arthropods and molluscs. Arthropod and mollusc hemocyanins are different in amino acid sequences of functional units binding two copper atoms and in their quaternary structure, showing independent evolution, that is, convergent evolution of these oxygen transporting molecules. Spider hemocyanins, like those of other arthropods, are hexamers of about $75 \mathrm{kDa}$ subunit peptides or multiples of these hexamers (VAN HOLDE \& MILLER, 1995). The heterogeneity of the monomer subunits was demonstrated by means of polyacrylamide gel electrophoresis for hemocyanins from chelicerates including several spiders (SUGITA \& SEKIGUCHI, 1975; MARKL et al., 1979). The complete amino acid sequences of the subunits were determined for the chelicerate hemocyanins

1) Master's Program in Biosystem Studies, University of Tsukuba 筑波大学バイオシステム研究科

2) Institute of Biological Sciences, University of Tsukuba, Tsukuba, Ibaraki 305, Japan 干 305 茨城県つくば市天王台 1-1-1 筑波大学生物科学系

*Corresponding author

Accepted October 24, 1997 
from a spider Eurypelma californicum (SCHARTAU et al., 1983; SCHNEIDER et al., 1983; VOIT \& FELDMAIER-FUCHS, 1990), a scorpion Androctonus australis (BUZY et al., 1995) and horseshoe crabs Tachypleus tridentatus (LINZEN et al., 1985) and Limulus polyphemus (NAKASHIMA et al., 1986). All chelicerate hemocyanin subunits completely sequenced to date display a considerable degree of similarity from $53 \%$ to $65 \%$ within a species (the spider), between genera (the horseshoe crabs), between orders (the spider and the scorpion), and between classes (the horseshoe crabs and the spider or scorpion). Using these complete amino acid sequence data, phylogeny inference programs produced branching patterns for the hemocyanin subunits (BEINTEMA et al., 1994; SugitA \& SHIShiKURA, 1995; BuRMESTER \& SCHELler, 1996). For example, both programs of neighbor-joining and UPGMA (unweighted pairgroup method with arithmetic means) analyses gave a node from which two branches diverged. One branch included the $T$. tridentatus hemocyanin subunit HT6 and the $E$. californicum hemocyanin subunit a, and another included the $L$. polyphemus hemocyanin subunit LimII and the E. californicum hemocyanin subunit e. Therefore, these hemocyanin subunits did not give any tree of animal evolution but gave evolutionary trees of hemocyanin molecules. To produce a phylogenetic tree of animal species, we must choose orthologous hemocyanin subunits derived from a common ancestor out of many subunits. The N-terminal amino acid sequence analysis is thought to be a good method to find orthologous hemocyanin subunits in many homologues between species. In this paper, the N-terminal amino acid sequences of hemocyanin subunits from four araneid spiders and a pisaurid spider are reported. The evolutionary events in these spider's hemocyanins are discussed based on sequence comparison.

\section{Materials and Methods}

Four araneid spiders Argiope amoena, A. bruennichii, Araneus ventricosus, Nephila clavata, and a pisaurid spider Dolomedes sulfureus collected from Tsukuba, Ibaraki prefecture. Hemolymph was collected by puncturing the heart with a micro-syringe and kept with a roughly equal volume of glycerin at $-20^{\circ} \mathrm{C}$.

$7.5 \%$ polyacrylamide disc and slab gels at $\mathrm{pH} 8.9$ were prepared according to the method of DAVIS (1964). Native hemocyanin electrophoresed was previously incubated in electrophoresis buffer of DAVIS to dissociate hexamers into monomer subunits. The hemocyanin subunits in a disc gel were re-electrophoresed into a slab gel.

The subunits in the slab gel were transferred to a polyvinylidene difluoride (PVDF) sheet which was activated for $1 \mathrm{~min}$ in $100 \%$ methanol and soaked in transfer buffer.

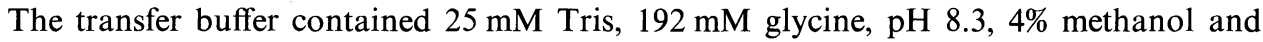
$0.02 \%$ sodium dodecyl sulfate. Electrophoretic transfer was carried out for $6 \mathrm{hr}$ at 2.4 $\mathrm{mA} / \mathrm{cm}^{2}$ in a blotting apparatus (TowBIN et al., 1979). The PVDF sheet containing the hemocyanin subunits were stained for 15 minutes with a Coomassie blue solution ( $0.1 \%$ in $42 \%$ methanol $/ 17 \%$ acetic acid) and destained for a few minutes with $90 \%$ methanol, washed with distilled water and then dried overnight.

The protein spots stained were cut out and mounted in the reaction chamber of a protein sequencer. N-terminal sequence analysis was performed with an Applied Biosystems model 477A gas phase sequencer equipped with an online model 120A PTH-analyzer. 


\section{Results and Discussion}

Two dimensional electrophoresis using polyacrylamide gels revealed that A. bruennichii and $D$. sulfureus had four hemocyanin subunits named Ab1-Ab4 and Ds1-Ds4, respectively and that each of all subunit spots in slab gels was accompanied by a long tail (Fig. 1). These parallel tails in the slab gel of the second electrophoresis suggest the overlapped existence of subunit molecules in the disc gel of the first electrophoresis. This means that, though native hemocyanins were pre-incubated to be dissociated into monomer subunits, they were dissociated incompletely and monomer subunits dissociated from hexamers were electrophoresed successively into the disc gel. Consequently, subunits of these spider hemocyanins are not separated completely from each other by the first disc gel electrophoresis. As shown Fig. 1, however, we could separate the two hemocyanins into their individual subunits using the second slub gel. Similarly, hemocyanins of $A$. amoena, $A$. ventricosus and $N$. clavata were separated into 5 (Aa1-Aa5), 6 (Av1-Av6) and 6 (Nc1-Nc6) subunits, respectively, by the two dimensional electrophoresis.

Direct protein sequencing of the hemocyanin subunits transferred to the PVDF sheet gave the sequences for the first 10-25 amino acid residues as shown in Fig. 2. The subunits, Aa1, 2, Ab1, 2, 4, Av1-3, 5, Nc1, 2 and Ds4 did not respond to automated Edman degradation, suggesting blocked amino terminals. Like most chelicerate hemocyanin subunits, the subunits sequenced possessed lysine-glutamine and leucinephenylalanine residues in positions 5-6 and 12-13, respectively, except for undetermined residues indicated by $\mathrm{X}$ and Ds1-3 whose residues in position 6 were valine or glutamic acid.

In the araneid spiders, there are hemocyanin subunits with $\mathrm{N}$-terminal sequences "PAQDKQ" and "TVKDKQ" for the first six residues. These subunits with "PAQDKQ" were identical except for residues in position 21 of Aa3 and Nc3. This means that

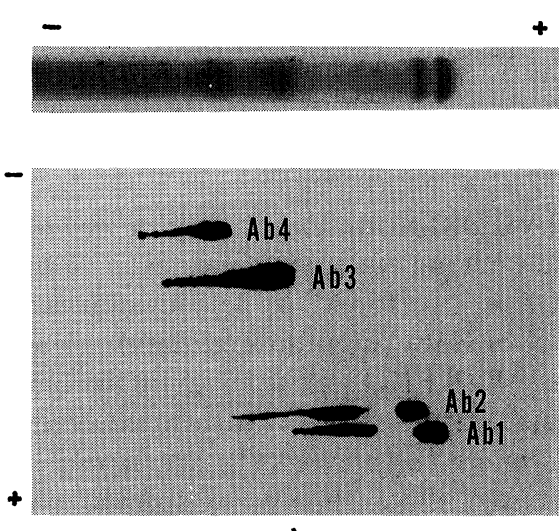

A
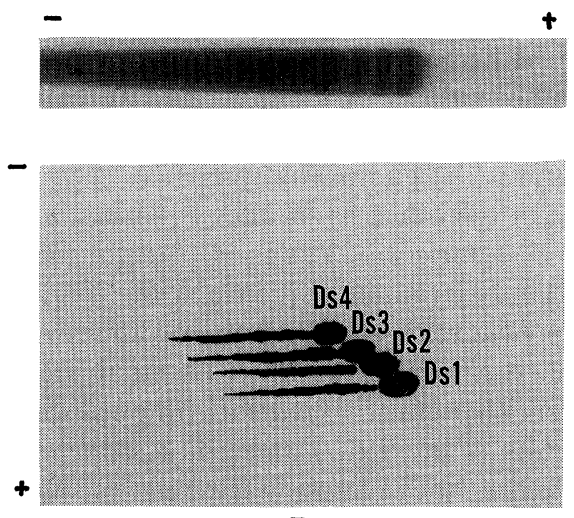

B

Fig. 1. Electrophoretic patterns of hemocyanins from A. bruennichii (A) and $D$. sulfureus (B). Protein molecules were electrophoresed from the cathode to the anode. Hemocyanin subunits of $A$. bruennichii and $D$. sulfureus were named Ab1-4 and Ds1-4, respectively in order of mobility. 


$\begin{array}{ll}\text { Aa3 } & \text { PAQDKQRRILPLFEHLASXTKXILP } \\ \text { Aa4 } & \text { PAQDKQRRILPXFEH } \\ \text { Aa5 } & \text { TVKDKQXRILP } \\ \text { Ab3 } & \text { PAQDXQRRILPL } \\ & \text { Pv4 } \\ \text { Av6 } & \text { TVKDKQAKILPXFKNLTSLXPE } \\ & \\ \text { Nc3 } & \text { PAQDKQRRILPLFEHLASXTR } \\ \text { Nc4 } & \text { PAQDKQRRILPLFEHLASXT } \\ \text { Nc5 } & \text { PAQDKQXXIL } \\ \text { Nc6 } & \text { PAQDKQRXILP } \\ & \\ \text { Ds1 } & \text { TIKDKVDRILPLFEQMTTXT } \\ \text { Ds2 } & \text { TIKEKEDRILPLFENLT } \\ \text { DS3 } & \text { TIKEKEDRILPLFENLT }\end{array}$

Fig. 2. N-terminal amino acid sequences of hemocyanin subunits from A. amoena (Aa3-5), A. bruennichii (Ab3), A. ventricosus (Av4 and 6), N. clavata (Nc3-6) and D. sulfureus (Ds1-3). Undetermined residues are indicated by $\mathrm{X}$.

these similar sequences derived from a common ancestral sequence and suggests that duplications of the ancestral sequence with "PAQDKQ" occurred in the lineages of $A$. amoena and $N$. clavata or in the common ancestor immediately before the divergence of these two araneid spiders and then in the lineage of $N$. clavata. Concerning sequences with "PAQDKQ", we cannot deny possibility of the existence of allelic products in $A$. amoena and $N$. clavata, but there are at least two products of two distinct loci in Nc3-6 because hemocyanin sample from an individual $N$. clavata was used for electrophoresis. In either case, it is thought that we can produce a phylogenetic tree of these araneid spiders from complete amino acid sequence data of these similar subunits by computer programs for phylogeny inference.

On the other hand, the sequences with "TVKDKQ" are found only in $A$. amoena and $A$. ventricosus, not in $A$. bruennichii which belongs to same genus as A. amoena. Similar N-terminal sequence with "TVKDKQ" is also found in hemocyanin subunit from Typopeltis sp. (Pseudoscorpiones: Thelyphonidae) (unpublished data). Furthermore, the subunits with N-terminal sequence "TVKEKQ" exist in a liphistiomorph spider Heptathela kimurai (unpublished data), a scorpion Androctonus australis (JOLLÈs et al., 1979) and a horseshoe crab Limulus polyphemus (LAMY et al., 1983). Therefore, the evolutionary relationships between these chelicerate species may be displayed by a comparative study of the complete amino acid sequences of their hemocyanin subunit molecules.

On the contrary, the N-terminal sequences with "TIKDKV" or "TIKEKE" found in the pisaurid spider $D$. sulfureus are not reported until now. We can see a resemblance between the sequences "TIKDKV" or "TIKEKE" and "TVKDKQ" or "TVKE- 
KQ". However, because the former have a valine (V) or glutamic acid (E) in position 6 where most chelicerate hemocyanins possess a glutamine $(Q)$, the subunits with the $\mathrm{N}$-terminal sequences "TIKDKV" and "TIKEKE" are unique hemocyanin subunits to D. sulfureus.

To further comparative study of these spider hemocyanins, N-terminal sequences of de-blocked amino terminals are required, although their chemical and physiological properties differ from the sequences with not blocked amino terminals.

\section{Acknowledgments}

We thank Mrs. H. KoNDO for amino acid sequence analysis.

コガネグモ類 4 種およびキシダグモ類 1 種のへモシアニンをアクリルアミドゲルを用 いた二次元電気泳動によりモノマーサブュニットに分離し，各サブュニットの $\mathrm{N}$ 末端ア ミノ酸配列を分析した.どの種にも $\mathrm{N}$ 末端が修飾されているために $\mathrm{N}$ 末端配列分析ので きないサブユニットが 1 個から数個存在していた。

$\mathrm{N}$ 末端アミノ酸配列比較から，コガネグモ類のへモシアニンには 2 種類の配列があ り，その一方はコガネグモとジョロウグモの系統か, あるいはコガネグモとジョロウグ モの共通の祖先の系統で重複し，数を増したと推定された。これらのサブユニットの全 配列を比較すれば，コガネグモ類の分岐パターンを知ることができる．コガネグモ類の もう一方の配列に似た $\mathrm{N}$ 末端を持つサブユニットが，キムラグモとサソリモドキ，サソ リおよびカブトガニ類にも存在しているので，これらのサブュニットを調べれば，これ らの鈇角類の関係を明らかにできる。

イオウイロハシリグモは, これまで全く他のへモシアニンで報告されていない $\mathrm{N}$ 末端 アミノ酸配列を持っていた。

\section{References}

Beintema, J. J., W. T. Stam, B. Hazes, \& M. P. SmidT, 1994. Evolution of arthropod hemocyanins and insect storage proteins (hexamerins). Mol. Biol. Evol., 11: 493-503.

BURMESTER, T., \& K. SCHELlER, 1996. Common origin of arthropod tyrosinase, arthropod hemocyanin, insect hexamerin, and dipteran arylphorin receptor. J. mol. Evol., 42: 713-728.

Buzy, A., J. Gagnon, J. Lamy, P. Thibault, E. Forest, \& G. Hudry-Clergeon, 1995. Complete amino acid sequence of the Aa6 subunit of the scorpion Androctonus australis hemocyanin determined by Edman degradation and mass spectrometry. Eur. J. Biochem., 233: 93-101.

DAvis, B. J., 1964. Disc electrophoresis-II. Method and application to human serum proteins. Ann. N. Y. Acad. Sci., 121: 404-427.

JOLLÈs, J., P. JOLLÈs, J. LAMY, \& J. LAMY, 1979. Structural characterization of seven different subunits in Androctonus australis haemocyanin. FEBS Lett., 106: 289-291.

Lamy, J, J. Lamy, P. -Y. Sizaret, P. Billiald, P. Jollès, J. Jollès, R. J. Feldmann, \& J. BONAVENTURA, 1983. Quaternary structure of Limulus polyphemus hemocyanin. Biochemistry, 22: $5573-5583$.

Linzen, B., N. M. Soeter, A. F. Riggs, H.-J. Schneider, W. Schartau, M. D. Moore, E. Yokota, 
P. Q. Behrens, H. Nakashima, T. Takagi, T. Nemoto, J. M. Vereijken, H. J. Bak, J. J. Beintema, A. Volbeda, W. P. J. Gaykema, \& W. G. J. Hol, 1985. The structure of arthropod hemocyanins. Science, 229: 519-524.

MARKL, J., A, MARKL, W. SchartaU, \& B. LinZen, 1979. Subunit heterogeneity in arthropod hemocyanins: I. Chelicerata. J. comp. Physiol., 130: 283-292.

Nakashima, H., P. Q. Behrens, M. D. Moore, E. YokotA, \& A. F. Riggs, 1986. Structure of hemocyanin II from the horseshoe crab, Limulus polyphemus. Sequences of the overlapping peptides, ordering the $\mathrm{CNBr}$ fragments, and the complete amino acid sequence. J. biol. Chem., 261: 10526-10533.

Schartau, W., F. Eyerle, P. Reisinger, H. Geisert, H. Storz, \& B. Linzen, 1983. Hemocyanins in spiders, XIX. Complete amino-acid sequence of subunit $d$ from Eurypelma californicum hemocyanin, and comparison to chain e. Hoppe-Seyler's Z. Physiol. Chem., 364: 1383-1409.

Schneider, H.-J., R. Drexel, G. Feldmaier, B. Linzen, F. LotTSPeich, \& A. Henschen, 1983. Hemocyanins in spiders, XVIII. Complete amino-acid sequence of subunit $e$ from Eurypelma californicum hemocyanin. Hoppe-Seyler's Z. Physiol. Chem., 364: 1357-1381.

Sugita, H., \& K. SeKIGUCHI, 1975. Heterogeneity of the minimum functional unit of hemocyanins from the spider (Argiope bruennichii), the scorpion (Heterometrus sp.), and the horseshoe crab (Tachypleus tridentatus). J. Biochem., 78: 713-718.

SugitA, H., \& F. ShishikURA, 1995. A case of orthologous sequences of hemocyanin subunits for an evolutionary study of horseshoe crabs: Amino acid sequence comparison of immunologically identical subunits of Carcinoscorpius rotundicauda and Tachypleus tridentatus. Zoological Sci., 12: $661-667$.

Towbin, H., T. StAehelin, \& J. GoRdON, 1979. Electrophoretic transfer of proteins from polyacrylamide gels to nitrocellulose sheets: Procedure and some applications. Proc. natl. Acad. Sci. $U S A$, 76: 4350-4354.

Van Holde, K. E., \& K. I. Miller, 1995. Hemocyanins. Adv. Prot. Chem., 47: 1-81.

VOIT, R., \& G. FELDMAIER-FUCHS, 1990. Arthropod hemocyanins. Molecular cloning and sequencing of cDNAs encoding the tarantula hemocyanin subunits a and e. J. biol. Chem., 265: 1944719452. 